\title{
GAMBARAN HARGA, KARAKTERISTIK PRODUK SERTA KEPUTUSAN PEMBELIAN MOBIL TOYOTA INNOVA DI BANDUNG
}

\author{
Lusiana Safitri \\ Universitas Pendidikan Indonesia \\ lusiana.safitri@student.upi.edu \\ Agus Rahayu \\ Universita Pendidikan Indonesia \\ agusrahayu@upi.edu
}

\begin{abstract}
ABSTRAK
Tujuan - Tujuan dari makalah ini adalah untuk mengetahui pengaruh harga dan karakteristik produk terhadap keputusan pembelian

Desain / metodologi / pendekatan - Penelitian ini dilakukan pada jangka waktu kurang dari 1 tahun, maka desain penelitian adalah desain cross-sectional. Dan metode yang digunakan adalah survei exolanatory, dan populasi 60 responden. Teknik analisis yang digunakan adalah deskriptif, kuesioner digunakan sebagai instrumen penelitian untuk mengumpulkan data dari responden.

Temuan - berdasarkan hasil penelitian menggunakan analisis regresi linier ganda, didapatkan hasil bahwa keputusan pembelian dipengaruhi oleh harga dan karakteristik produk secara signifikan dan positif.

Orisinalitas/nilai - penelitian ini memberikan dasar untuk memahami pengaruh dari harga dan karakteristik produk terhadap keputusan pembelian. Perbedaan penelitian ini dengan penelitian sebelumnya adalah pada objek, variabel, teori serta referensi yang digunakan.
\end{abstract}

Kata kunci: harga, karakteristik produk, keputusan pembelian

Jenis Artikel : Penelitian

\begin{abstract}
Objective - The purpose of this paper is to determine the effect of price and product characteristics on purchasing decisions

Design / methodology / approach - This research was conducted in less than 1 year period, so the research design is cross-sectional design. The method used is exolanatory survey, and population 60 respondents. The analysis technique used is descriptive, the questionnaire is used as a research instrument to collect data from respondents.

Finding - Based on the results of the study using multiple linear regression analysis, the result that there is a positive influence of price and product characteristics on purchase decision.

Originality / value - this study provides a basis for find out the impact of price and product characteristics on purchase decision. The difference of this study with previous research is on the objects, variables, theories and the reference.
\end{abstract}

Keywords: price, product characteristics, purchase decision.

Article Type: Research Paper 


\section{PENDAHULUAN \\ Latar Belakang}

Keputusan pembelian merupakan ukuran pengguna terhadap respon suka atau tidak suka menggunakan produk tertentu dan penentu utama perilaku pembelian di masa depan (Dharmesta \& Irawan, 2015). Dalam membeli suatu produk konsumen tidak langsung membeli begitu saja, tetapi mereka mengidentifikasi terlebih dahulu apa yang mereka inginkan (Rahayu, 2009). Mengukur keputusan pembelian memberikan indikasi diterima atau tidak suatu sistem dalam perilaku konsumen (Tha Kur dan Srivastava, 2013).

Konsumen dalam mengambil keputusan didasarkan pada motif rasional, motif emosional atau keduanya. Motif rasional melibatkan evaluasi logis dari atribut produk yaitu biaya, kualitas, dan kegunaan. Motif emosional melibatkan faktor non objektif dan termasuk sosialisasi, meniru orang lain dan estetika (Manullang, 2012). Keputusan untuk membeli dapat mengarah kepada bagaimana proses dan pengambilan keputusan tersebut itu dilakukan (Schiffman dan Kanuk, 2014). Keputusan pembelian produk otomotif merupakan hal yang penting karena berkaitan dengan kebutuhan keluarga akan sarana transportasi yang dibutuhkan (Prieto, 2012). Diantara berbagai jenis kendaraan roda empat, salah satu jenis yang paling banyak diminati konsumen, yakni kendaraan serba guna atau Multi Purpose Vehicle (MPV). MPV adalah jenis kendaraan yang difungsikan untuk mengangkut banyak penumpang atau sebagai mobil keluarga. Saat ini, mobil jenis MPV banyak digemari oleh sebagian besar orang, sehingga banyak produsen dari berbagai perusahaan memproduksi mobil jenis MPV (Automotifzone.com, 2015). Berikut market share mobil MPV berdasarkan merek enam terlaris di Indonesia.
Tabel 1

MARKET SHARE MOBIL MULTI PURPOSE VEHICLE (MPV) ENAM TERATAS TAHUN 2013-2016

\begin{tabular}{|c|c|c|c|c|}
\hline MOBIL & 2013 & 2014 & 2015 & 2016 \\
\hline Toyota Avanza & $28,4 \%$ & $35,8 \%$ & $35,2 \%$ & $43.6 \%$ \\
\hline Toyota Innova & $24,1 \%$ & $16,8 \%$ & $13,6 \%$ & $11.1 \%$ \\
\hline Suzuki APV & $12,5 \%$ & $10,0 \%$ & $12,5 \%$ & $14.0 \%$ \\
\hline Daihatsu Xenia & $10,9 \%$ & $14,9 \%$ & $14,8 \%$ & $14.1 \%$ \\
\hline Isuzu Phanter & $4,2 \%$ & $2,6 \%$ & $2,6 \%$ & $3.9 \%$ \\
\hline $\begin{array}{l}\text { Nissan Grand } \\
\text { Livina }\end{array}$ & $3,3 \%$ & $3,3 \%$ & $2,8 \%$ & $3.3 \%$ \\
\hline
\end{tabular}

Tabel 1 menunjukkan jenis mobil MPV dari berbagai merek, indeks Toyota Innova menempati peringkat kedua. Penjualan Toyota Innova mengalami penurunan di tahun 2014 sebesar 7,3\% pada tahun 2015 Toyota Kijang Innova menurun sebanyak $3,2 \%$ dan penurunan di tahun 2016 sebanyak $2,5 \%$.

Rendahnya volume penjualan mobil Toyota innova menunjukan terjadinya penurunan keputusan pembelian konsuman terhadap mobil tipe MPV ini. Akibat dari terus menurunnya penjualan MPV Nasional membuat sebagian besar produsen MPV mengalami penurunan penjualan yang drastis (Automotifzone.com, 2015). Permasalahan dalam menurunnya volume penjualan MPV ini bukan hanya karena adanya perlambatan pertumbuhan ekonomi, namun disebabkan oleh perilaku konsumen yang berbeda kepada setiap produk.Penurunan penjualan ini menyebabkan penurunan tingkat pendapatan yang tidak seimbang dengan beban upah karyawan yang tetap. Penurunan yang tidak segera diatasi akan berdampak pada produksi yang akan dihentikan bagi produsen yang mengalami pertumbuhan penjualan negatif karena akan merugikan perusahaan disebabkan produknya tidak bisa diserap oleh pasar (Younus, 2015).

Keputusan pembelian dapat ditingkatkan sesuai dengan penelitian terdahulu yaitu apabila ada pengaruh positif dan signifikan dari faktor harga dan karakteristik produk (Hidayat, Elita, dan Setiaman, 2012) Penelitian lain menjelaskan bahwa produk, harga, lokasi, dan promosi berpengaruh terhadap keputusan konsumen untuk membeli (Ulus, Wangko, Evelina, 2013). Faktor harga, persepsi, dan sikap konsumen juga memiliki pengaruh secara signifikan pada keputusan pembelian (Irawan, 2015). Produk adalah segala sesuatu yang dapat ditawarkan kepasar 
untuk mendapatkan perhatian, dibeli, digunakan, atau dikonsumsi yang dapat memuaskan keinginan atau kebutuhan (Philip Kotler dan Peter Keller, 2012).

\section{Tinjauan Pustaka \\ Pemasaran}

Pemasaran sebagai suatu seni dan ilmu untukmemiih sasaran pasar dan mendapatkan pelangganmelalui menciptakan dan mengkomunikasikan nilai pelanggan yang unggul (Tanjungsewu dan Lisnawati, 2016). Pemasaran adalah proses sosial yang dengan proses itu individu dan kelompok mendapatkan yang mereka butuhkan dan ingingkan dengan menciptakan, menawarkan, dan secara bebas mempertukarkan produk dan jasa yang bernilai dengan pihak lain (Rahayu, 2009).

Pemasaran adalah suatu proses yang diterapkan perusahaan untuk memenuhi kebutuhan dan keinginan konsumen dengan menyediakan produk (barang dan jasa) (Machfoedz, 2010). Konsumen tertentu yang merupakan sasaran upaya pemasaran disebut pasar sasaran (Subagyo, 2010). Tujuan pemasaran adalah apa yang ingin kita capai, sebuah tujuan pemasaran memperhatikan keseimbangan antara produk dan target pasar. Ini berhubungan dengan produk apa yang kita jual pada pasar tertentu supaya meningkatkan volume penjualan, memberikan kepuasan kepada pelanggan, dan memaksimalkan laba (Subagyo, 2010). Tugas pemasar adalah menyusun program atau rencana pemasaran untuk mencapai tujuan yang diinginkan perusahaan. Program pemasaran terdiri dari sejumlah keputusan tentang bauran alat-alat pemasaran yang digunakan. "Bauran pemasaran (marketing mix) adalah seperangkat alat pemasaran yang digunakan perusahaan untuk terus menerus mencapai tujuan pemasarannya di pasar sasaran" (Rahayu, 2009).

\section{Harga}

Harga adalah satu unsur bauran pemasaran yang menghasilkan pendapatan sedangkan yang lainnya menghasilkan biaya (Philip Kotler dan Peter Keller, 2012). Harga adalah segala bentuk biaya moneter yang dikorbankan oleh konsumen untuk memperoleh, memiliki, memanfaatkan sejumlah kombinasi dari barang beserta pelayanan dari suatu produk. Perusahaan harus menetapkan harga jual untuk yang pertama kalinya, terutama pada saat mengembangkan produk baru. Penetapan harga jual berpotensi menjadi suatu masalah karena keputusan penetapan harga jual cukup kompleks dan harus memperhatikan berbagai aspek yang mempengaruhinya (Hasan, 2011).

Hasil pengujian menunjukkan pengaruh harga terhadap keputusan pembelian mobil Toyota Innova adalah signifikan dan positif. Hasil ini mengindikasikan bahwa semakin baik strategi harga yang ditawarkan oleh perusahaan akan membuat konsumen semakin senang, sehingga mereka akan mau membeli produk tersebut. Penerapan strategi menetapkan harga merupakan salah satu faktor penting dalam menarik minat konsumen untuk membeli. Misalnya memberikan potongan harga, harga yang terjangkau, strategi harga yang kompetitif, harga yang diterapkan sesuai dengan kualitas maupun manfaat produk yang dijual menjadi perhatian utama konsumen atau calon konsumen untuk membeli perusahaan. Semakin baik penerapan strategi harga semakin menarik minat konsumen untuk membeli tersebut. Hasil ini sejalan dengan pendapat yang dikemukakan oleh (Simamora, 2010) Penetapan harga harus diperhatikan dan dipertimbangkan. Agar harga produk menimbulkan minat konsumen maka penetapan harga harus sesuai atau memadai dengan tolak ukur konsumen (dengan kata lain bahwa harga ditetapkan tidak terlalu tinggi dan tidak terlalu rendah), sesuai dengan kualitas produk serta pemberian discount oleh perusahaan sesekali juga perlu mendapat perhatian agar dapat menarik konsumen sasaran.

\section{Karakteristik Produk}

Karakteristik dapat diartikan kemampuan dari produk untuk menjalankan fungsinya yang mencakup daya tahan, kehandalan atau kemajuan, kekuatan, kemudahan dalam pengemasan dan reparasi produk dan ciri-ciri lainnya (Younus, 2015). Produk didefinisikan sebagai persepsi konsumen yang dijabarkan oleh produsen melalui hasil produksinya Mutu atau kualitas produk dipengaruhi oleh faktor yang menentukan bahwa mutu barang dapat memenuhi tujuannya, yaitu untuk meningkatkan volume penjualan (Iswayanti, 2010). Harga membantu konsumen untuk menentukan seseorang akan membeli barang 
atau tidak. Suatu perusahaan menentukan nilai untuk mendapatkan laba dari produk yang dijual perusahaan tersebut. Untuk menentukan harga suatu produk atau jasa, ada beberapa dasar yang harus dipertimbangkan (Machfoedz, 2010).

Karakteristik produk merupakan keyakinan satu pihak mengenai maksud dan perilaku pihak yang lainnya, dengan demikian kepercayaan konsumen didefinisikan sebagai harapan konsumen bahwa penyedia produk atau jasa dapat dipercaya dan diandalkan dalam memenuhi janjinya (Sirdesmukh, 2012). Karakteristik produk adalah kondisi tentang spesifikasi (relatif terhadap orang lain) dan menilai ukuran sejauh mana konsumen dapat merasakan bahwa suatu merek dapat memiliki atribut tertentu (Solomon, 2013). Karakteristik produk pada bisnis otomotif umumnya berasal dari kredibilitas perusahaan. Kredibilitas didefinisikan apakah perusahaan mampu memberikan produk yang bermutu, kompeten dan dapat diandalkan (Han dan Windsor, 2011).

\section{Keputusan Pembelian}

Konsep karakteristik produk sendiri mengacu pada sejauh mana pengetahuan tentang produk yang dianggap menarik untuk diri konsumen. Karakteristik produk diartikan sebagai deskripsi yang diperoleh dari proses pembelian (Kwek et al., 2010). Salah satu faktor yang mempengaruhi keputusan konsumen dalam pembelian mobil Toyota Innova adalah mengenai aspek produk. Produk adalah merupakan sesuatu yang ditawarkan oleh perusahaan kepada konsumen yang lebih mengarah kepada kebutuhan konsumen akan mobil Toyota Innova, yang berkaitan dengan kualitas, jenis dan tipe mobil Toyota Innova, kehandalan, keiritan dalam pemakaian bahan bakar. Para pembeli dihadapkan pada beberapa faktor yang menjadi pertimbangan dalam melakukan pembelian, diantaranya adalah harga, prestise, teknik, dan desain. Begitu pula halnya produsen ketika menjual produknya, ia dihadapkan pada ketatnya persaingan, menciptakan inovasi menjadi salah satu cara yang cukup ampuh untuk menarik perhatian dan keputusan pembelian konsumen (Rahayu, 2009). Keputusan pembelian merupakan sikap seseorang untuk membeli atau menggunakan suatu produk baik berupa barang atau jasa yang telah diyakini akan memuaskan dirinya dan kesediaan menanggung resiko yang mungkin ditimbulkanya. Keputusan pembelian yang diambil oleh pembeli sebenarnya merupakan kumpulan dari sejumlah keputusan yang terorganisir (Adirama, 2012). Keberhasilan suatu usaha dapat dilihat dari frekuensi penjualan setiap bulannya. Apabila frekuensi setiap bulannya mengalami kenaikan maka perusahaan tersebut dapat dikatakan berhasil dan apabila mengalami penurunan secara terus menerus setiap bulannya maka perusahaan tersebut harus mengamati mengapa terjadi penurunan (Rahayu, 2009).

Salah satu strategi yang dapat dilakukanoleh perusahaan untuk mencapai tujuannya yaitudengan menerapkan strategi marketing mix ataubauran pemasaran. Strategi tersebut digunakanuntuk mendapatkan keuntungan bagi perusahaan.Bauran pemasaran sebagai salah satu elemen dalam inti pemasaran merupakan cara produsendalam mengedukasi konsumen terhadap sebuahproduk atau jasa (Deniami dan Lisnawati, 2016).

Adapun dimensi keputusan pembelian dalam penelitian ini adalah brand choice, place, timing, dan payment method (Tjiptono, 2012). Berdasarkan pemaparan diatas maka diambil paradigma penelitian sebagai berikut:

\section{Gambar 1 : Paradigma Penelitian}

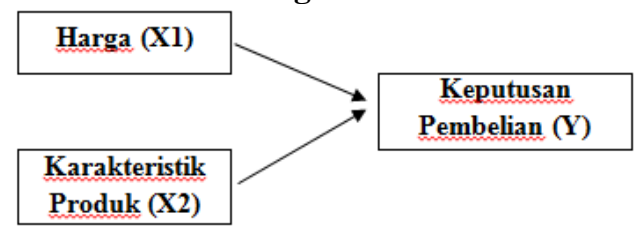

\section{Hipotesis}

Hipotesis yang diajukan adalah:

H1 : Harga dankarakteristik produk diduga secara bersama berpengaruh terhadap keputusan pembelian

H2 : Harga diduga berpengaruh terhadap keputusan pembelian.

H3 :Karakteristik produk diduga berpengaruh terhadap keputusan pembelian.

\section{Metode Penelitian}

Penelitian ini dilakukan untuk mengetahui pengaruh harga dan kualitas terhadap keputusan pembelian mobil MPV. Adapun yang menjadi objek penelitian sebagai variabel $X$ atau variabel bebas 
(independent variabel) adalah harga (X1) dengan dimensinya yang mencakup; 1) Price List (Daftar Harga), 2) Discount (Potongan Harga), 3) Allowance (Potongan Harga Khusus), 4) Payment Period (Periode Pembayaran) dan 5) Credit Term (Syarat Kredit). Karakteristik produk (X2) dengan dimensinya; 1) Variety (Keberagaman), 2) Features (Fitur), 3) Design (Model), 4) Brand (Merek) dan 5) Service (Servis). Masalah penelitian yang merupakan variabel (Y) atau variabel terikat (dependent variabel) adalah keputusan pembelian dengan dimensinya yang mencakup; 1) Brand Choice (Pilihan Merek), 2) Place 3) Timing (Waktu) dan 4) Payment Method (Metode Pembayaran).

Unit analisis yang dijadikan responden dalam penelitian ini adalah Anggota Kaskus Innova Owner Community. Oleh karena itu akan diteliti pengaruh harga karakteristik produk tehadap keputusan pembelian anggota Kaskus Innova Owner Community. Penelitian ini dilakukan dalam kurun waktu kurang dari satu tahun, maka metode yang digunakan adalah cross sectional method, pengumpulan informasi dari subjek penelitian hanya dilakukan satu kali dalam satu periode waktu, sehingga penelitian ini merupakan cross sectional.Penelitian ini dilakukan pada anggota Kaskus Innova Owner Community di kota Bandung. Penelitian ini dilakukan selama 3 bulan dimulai pada bulan juni 2017 dan berakhir pada bulan Agustus 2017. Penelitian ini menggunakan teknik analisis data deskriptif yang digunakan untuk melihat pengaruh harga dan karakteristik produk terhadap keputusan pembelian.

Metode penelitian yang digunakan adalah metode explanatory survey. Explanatory survey dilakukan untuk mengeksplorasi situasi masalah, yaitu untuk mendapatkan ide-ide dan wawasan kedalam masalah yang dihadapi manajemen atau para peneliti tersebut (Malhotra, 2011). Penelitian eksplanatori bertujuan untuk menjelaskan hubungan antara dua atau lebih gejala atau variabel (silalahi, 2012). Explanatory survey dilakukan melalui kegiatan pengumpulan informasi dari sebagian populasi secara langsung di tempat kejadian (empirik) melalui kuesioner dengan tujuan untuk mengetahui pendapat dari sebagian populasi yang diteliti terhadap penelitian.

\section{Hasil Penelitian Dan Pembahasan}

Berdasarkan kusioner yang disebar oleh peneliti, diperoleh data yang mengungkap distribusi responden berdasarkan demografi responden. Dari kuesioner data tersebut terungkap distribusi responden sebagai berikut: anggota Kaskus OwnerInnova Community (KIOC) paling banyak diikuti oleh anggota berusia 26-35 tahun yaitu sebanyak 17 orang yang didominasi oleh anggota laki-laki yaitu sebanyak 44 orang.

Hasil perolehan pendidikan terakhir menunjukan bahwa jumlah pendidikan terakhir tertinggi adalah jenjang S1, dan status pekerjaan pegawai swasta. Pendidikan dan pekerjaan merupakan lingkungan yang mempengaruhi gaya hidup, termasuk pada penggunaan media sosial. Hasil tersebut menjelaskan bahwa pekerjaan yang sedang ditempuh akan mempengaruhi pada keputusan bergabung menjadi anggota KIOC. Berdasarkan penetlian terhadap anggota $K I O C$ didapatkan hasil yang didominasi dengan yang berpenghasilan Rp.3.000.000Rp.5.000.000 dengan jumlah 25orang.Sedangkan perolehan terbanyak kedua adalah anggota yang berpenghasilan Rp.5.000.000-Rp.10.000.000. Hasil tersebut menunjukan bahwa penghasilan dimiliki oleh seseorang mempengaruhi dalam keanggotaan $K I O C$. Kemapanan ekonomi seseorang dalam pekerjaan dan penghasilan akan berpengaruh terhadap kelas sosial di masyarakat (Saladin, 2013).

Berdasarkan hasil perolehan data kuesioner menunjukan bahwa pengguna Innova terbanyak menggunakan type G 2000 cc sebesar $16,7 \%$ atau 10 orang dan lama menggunakan selama 1-2 tahun sebanyak $25 \%$ atau 15 orang. Perolehan kedua terbesar untuk type V Luxury $2000 \mathrm{cc}$ dan type G 2500 cc sebanyak $15 \%$ atau 9 orang. Secara keseluruhan pada industry otomotif, tingkat keputusan pembelian bagi Kijang Innova diasumsikan masih cukup baik melihat presentase terbesar lamanya penggunaan berasa dikisaran 1-2 tahun yaitu sebesar $25 \%$.Artinya hampir setengahnya dari pengguna Innova dalam rentang waktu 1-2 tahun tidak berpindah merek.

Berdasarkan hasil perolehan data diatas menunjukan bahwa anggota KIOC menggunakan mobil merek lain terbanyak memilih merek lainnya, yaitu sebesar 18 orang dengan presentase $30 \%$. Perolehan 
kedua terbesar untuk mobil merek Honda yaitu sebesar 16 orang dengan presentase $27 \%$.

Hasil penelitian berdasarkan alasan menggunakan mobil innova. Nilai terbesar adalah digunakan untuk keperluan keluarga yaitu $41,7 \%$ atau 25 responden. Faktor kedua adalah digunakan untuk keperluan bisnis/kerja yaitu sebanyak $31,7 \%$ atau 19 responden. Selebihnya digunakan untuk disewakan/rental sebanyak $13,3 \%$ atau 8 responden, keperluan lainnya sebanyak $8,3 \%$ atau 5 responden,dan angkutan umum/taxi sebanyak $5 \%$ atau 3 responden.

Pengaruh Harga Terhadap Keputusan Pembelian: Harga merupakan satu-satunya unsur bauran pemasaran yang memberikan pemasukan atau pendapatan bagi perusahaan (Philip Kotler dan Peter Keller, 2012).

Tabel 2

\begin{tabular}{cccccc} 
No & Dimensi & $\begin{array}{c}\text { Skor } \\
\text { Ideal }\end{array}$ & $\begin{array}{c}\text { Skor } \\
\text { Total }\end{array}$ & $\begin{array}{c}\text { Skor } \\
\text { Rata- } \\
\text { Rata }\end{array}$ & $\%$ \\
\hline 1 & Price List & 1680 & 1189 & 297.25 & 71 \\
2 & Discount & 840 & 567 & 283.5 & 68 \\
3 & Payment Period & 840 & 553 & 276.5 & 66 \\
4 & Credit Term & 840 & 581 & 290.5 & 69 \\
\hline$\quad$ Total Skor & $\mathbf{4 2 0 0}$ & $\mathbf{2 8 9 0}$ & $\mathbf{1 1 4 7 . 7 5}$ & $\mathbf{6 9}$ \\
\hline
\end{tabular}

Indikator dari dimensi price tagyang mendapat nilai tertinggi yaitu pada Kelengkapan daftar harga mobil Toyota Innova semua type dengan persentase sebesar $72 \%$ artinya kelengkapan terhadap daftar hargadan pengetahuan saat belanja ini merupakan nilai yang baik bagi perusahaan otomotif. indikator dari dimensi discount yang mendapat nilai tertinggi yaitu pada tingkat ketertarikan konsumen dalam menanggapi discount yang ditawarkan olehdealer dengan presentasenya $68 \%$. Artinya discount dianggap sebagai hal penting oleh konsumen, tingkat ketertarikanoleh konsumen tergantung dengan persepsi masing-masing konsumen terutama discount yang lebih menarik. indikator dari dimensi payment period mendapat skor tertinggi 291 pada Kemudahan memperoleh periode waktu pembayaran dengan berbagai pilihan angsuran di dealer.

Keputusan pembelian tidak hanya informasi yang mereka dapat tetapi jugan mempertimbangkan faktor harga dan karakteristik produk dapat memberikan perhatian yang lebih bagi konsumen karena dengan tingkat kualitas produk yang tinggi serta harga yang terjangkau dapat mengubah pelanggan yang puas menjadi loyal (Bruner dan Kumar, 2015).

Temuan atau hasil pengolahan data menunjukan bahwa dimensi yang memperoleh skor tertinggi adalah dimensi price list dengan presentase sebesar $71 \%$. Sedangkan tanggapan yang terendah adalah pada dimensi payment period dengan presentase sebesar $66 \%$. Dimensi price tag yang menjadi nilai tertinggi, dikarenakan kemudahan dalam memperoleh informasi dan bertransaksi pada dealer yang tentunya sudah sangat dipahami prosedurnya oleh para konsumen, khususnya para anggota KIOC. Indikator lain yang menjadi pertimbangan adalah discount dan credit term.

Hasil penelitian mengungkapkan bahwa indikator dari karakteristik produk pada dimensi variety mendapat nilai tertinggi yaitu pada tingkat keragaman tipe mobil Toyota Innova. Sedangkan untuk perolehan skor terendah yaitu tingkat keragaman warna mobil Toyota Innova mendapatkan perolehan persentase sebesar $73 \%$. Semakin beragam tipe Innova yang ditawarkan maka konsumen akan semakin tertarik untuk membuat keputusan pembelian. Keragaman tipe mobil lebih dari sekedar tipe mobil yang berbedabeda, tetapi lebih pada semua aspek tentang spesifikasi yang memiliki keunggulan di masing-masing jenisnya (Susanti dan Cholichul, 2013). indikator dari dimensi design yang mendapat skor 301 yaitu pada Tingkat kesesuaian model yang ditawarkan Toyota Innova dengan kontribusi sebesar $72 \%$. Kesesuaian model Toyota Innova mempengaruhi ketertarikan konsumen dalam memilih mobil yang akan dibelinya. indikator dari dimensi feature yang mendapat nilai tertinggi yaitu pada Keberagaman fungsi dan kegunaan pada setiap fitur saat digunakan pada kondisi lingkungan dengan skor total 287. Artinya fitur yang sesuai dengan lingkungan tempat konsumen tinggal dapat mempengaruhi pertimbangan konsumen untuk memilih mobil yang sesuai. Sedangkan untuk perolehan skor terendah yaitu Keberagaman fitur dari tipe produk Toyota Innova mendapatkan perolehan skor sebesar 285. Artinya fitur mobil yang disesuaikan dengan lingkungan konsumen tidak terlalu diperhatikan sebagai pertimbangan oleh konsumen. indikator dari dimensi brand yang mendapat nilai tertinggi yaitu pada Ketertarikan konsumen berdasarkan 
kepercayaan terhadap merek Toyota Innova yaitu sebesar $73 \%$. Artinya konsumen menganggap kualitas dari mobil Toyota Innova baik dan memberikan kepercayaannya atas merek tersebut. Sedangkan untuk perolehan skor terendah yaitu pada pengetahuan konsumen terhadap merek Toyota Innova mendapatkan perolehan persentase sebesar $70 \%$. Artinya pengetahuan konsumen terhadap merek Toyota Innova tidak terlalu diperhatikan sebagai pertimbangan untuk membeli mobil. Dan indikator dari dimensi service yang mendapat nilai tertinggi yaitu pada Ketersediaan layanan jasa yaitu sebesar $73 \%$. Artinya layanan jasa yang ditawarkan oleh perusahaan Toyota Innova tersedia dengan baik dan memberikan kemudahan konsumen untuk berkomunikasi mengenai mobil yang dibelinya tersebut. Sedangkan untuk perolehan skor terendah yaitu pada Ketersediaan sevice yang ditawarkan oleh dealer mendapatkan perolehan persentase sebesar $71 \%$. Artinya service yang ditawarkan oleh perusahaan tidak terlalu diperhatikan sebagai pertimbangan dalam membeli mobil.

Tabel 3

\begin{tabular}{cccccc}
\hline No & Dimensi & Skor Ideal & Skor Total & Skor Rata-rata & $\%$ \\
\hline 1 & Variety & 840 & 588 & 294 & 70 \\
2 & Design & 420 & 301 & 301 & 72 \\
3 & Feature & 840 & 572 & 286 & 68 \\
4 & Brand & 1260 & 903 & 301 & 72 \\
5 & Service & 1260 & 910 & 303.33 & 72 \\
\hline & Total & $\mathbf{4 6 2 0}$ & $\mathbf{3 2 7 4}$ & $\mathbf{2 9 7 . 6 4}$ & $\mathbf{7 1}$ \\
\hline
\end{tabular}

Berdasarkan hasil penelitian dimensi karakteristik produk yang memperoleh skor tertinggi adalah dimensi service dengan presentase sebesar $72 \%$. Sedangkan tanggapan yang terendah adalah pada dimensi feature dengan presentase sebesar 68\%. Dimensi service yang menjadi nilai tertinggi dikarenakan persepsi positif terhadap kepercayaan perusahaan dalam menjaga pelayananprima sehingga meningkatkan kepercayaan dari konsumen. Penjual yang ingin melakukan hal-hal positif seperti peduli dan terbuka kepada para konsumen memberikan service yang lebih tinggi (Seok dan Tan, 2013). Secara ideal skor yang diharapkan untuk jawaban anggota KIOC terhadap 11 pertanyaan adalah 4620. Dari perhitungan tersebut menunjukan persentasenya sebesar $71 \%$. Dengan demikian karakteristik produk berada pada kategori cukup tinggi. Perbandingan ini menunjukan bahwa pada pelaksanaannya para pelaku bisnis otomotif sudah memperhatikan aspek karakteristik produk. Karakteristik produk berkaitan positif dengan pengalaman konsumen dengan pihak penjual (Koufaris dan HamptonSOsa, 2012).

Hasil penelitian pada variable keputusan pembelian didapatkan bahwa indikator dari dimensi brand choice yang mendapat nilai tertinggi yaitu pada adanya Keputusan pembelian mobil Innova berdasarkan popularitas merek Toyota. Artinya popularitas merek merupakan nilai yang baik bagi perusahaan otomotif. Berkontribusi dengan persentase sebesar $74 \%$, sedangkan untuk perolehan skor terendah yaitu pada indikator Keputusan pembelian mobil Innova berdasarkan kepercayaan merek Toyota, dengan persentase $72 \%$. Faktor dalam kepercayaan terhadap suatu merek adalah kebutuhan untuk merasakan kualitas dari suatu merek tersebut tidak dapat dilakukan sebelum menggunakan (Grewal et al, 2012). indikator dari dimensi place yang mendapat nilai tertinggi yaitu pada Keputusan pembelian mobil Innova berdasarkan kemudahan menjangkau lokasi dealer. Artinya konsumen lebih tertarik melakukan pembelian mobil di dealer yang mudah dijangkau atau dekat dengan tempat tinggalnya. Berkontribusi dengan persentase sebesar $72 \%$. Perolehan skor terendah yaitu pada indikator keputusan pembelian mobil Innova berdasarkan kelancaran saluran distribusi dengan persentase sebesar $71 \%$. Artinya kelancaran saluran distribusi oleh perusahaan tidak terlalu diperhatikan oleh konsumen dalam mempertimbangkan keputusan pembelian. indikator dari dimensi timing yang mendapat nilai tertinggi yaitu Pertimbangan pembelian mobil Innova berdasarkan kebutuhan, artinya konsumen cenderung melakukan pembelian mobil berdasarkan kebutuhan. Berkontribusi dengan skor sebesar 316. Sedangkan untuk perolehan skor terendah yaitu pada indikator pertimbangan pembelian mobil Innova berdasarkan tawaran pembayaran kredit dengan cicilan ringan dengan persentase sebesar 69\%. Hal ini diartikan bahwa konsumen tidak terlalu memperhatikan penawaran cicilan ringan ketika tidak didasari dengan kebutuhannya membeli sebuah mobil. Dan indikator dari dimensi payment method yang mendapat nilai tertinggi yaitu pada pertimbangan pembelian mobil Innova berdasarkan kemudahan syarat pemberian 
kredit. Berkontribusi dengan persentase sebesar $72 \%$. Sedangkan untuk perolehan skor selanjutnya yaitu pada indikator pertimbangan pembelian mobil Innova berdasarkan metode pembayaran secara cash dengan persentase sebesar $71 \%$. Hal ini diartikan bahwa konsumen tidak terlalu tertarik melakukan pembelian mobil secara cash dan lebi mempertimbangkan membeli secara kredit dengan kemudahan metode pembayarannya.

Tabel 4.

\begin{tabular}{cccccc}
\hline No & Dimensi & Skor Ideal & $\begin{array}{c}\text { Skor } \\
\text { Total }\end{array}$ & $\begin{array}{c}\text { Skor } \\
\text { Rata-rata }\end{array}$ & $\begin{array}{c}\text { Presentase } \\
\%\end{array}$ \\
\hline 1 & Brand Choice & 840 & 616 & 308 & 73 \\
2 & Place & 840 & 601 & 300.5 & 72 \\
3 & Timing & 1260 & 920 & 306.67 & 73 \\
4 & Payment Method & 1260 & 897 & 299 & 71 \\
\hline & Total & $\mathbf{4 2 0 0}$ & $\mathbf{3 0 3 4}$ & $\mathbf{3 0 3 . 4}$ & $\mathbf{7 2}$ \\
\hline
\end{tabular}

Hasil penelitian pada variabel keputusan pembelian menunjukan bahwa dimensi yang memperoleh skor tertinggi adalah dimensi brand choice dengan presentase sebesar $73 \%$. Sedangkan tanggapan yang terendah adalah pada dimensi payment method dengan presentase sebesar $71 \%$. Indikator dari dimensi brand choice yang mempengaruhi perolehan skor yaitu popularitas merek Toyota. Sehingga menarik minat konsumen untuk membeli mobil merek Toyota Innova. Dimensi brand choice yang menjadi nilai tertinggi dikarenakan popularitas merek yang ditawarkan tersebut dianggap sudah lengkap dan jelas bagi konsumen. Keputusan pembelian konsumen dipengaruhi oleh jenis produk atau jasa yang sedang dipertimbangkan (Monshuwe, 2014).

Harga dan karakteristik produk menjadi hal yang penting dalam mempengaruhi keputusan pembelian. Kualitas dan aksesibilitas dealer, nilai produk atau jasa yang ditawarkan, integrasi umpan balik konsumen, review dan sistem rating merupakan faktor yang termasuk dalam pengaruh keputusan pembelian, sedangkan karakteristik produk dapat ditentukan oleh kepercayaan dari penjual itu sendiri (Lee Hao et al, 2014). Karakteristik produk berkaitan positif dengan pengalaman konsumen dengan pihak penjual (Koufaris dan Hampton Sosa 2012). Karakteristik produk adalah ketika salah satu pihak percaya bahwa pihak lain memiliki karakteristik bermanfaat bagi dirinya sendiri dan pihak lain (McKnight dan Chervany, 2013).

Semakin tinggi derajat kepercayaan konsumen terhadap produk, semakin tinggi tingkat pembelian niat konsumen (Gefen dan
Straub, 2014). Keputusan pembelian tidak hanya informasi yang mereka dapat tetapi jugan mempertimbangkan faktor harga dan karakteristik produk dapat memberikan perhatian yang lebih bagi konsumen karena dengan tingkat kualitas produk yang tinggi serta harga yang terjangkau dapat mengubah pelanggan yang puas menjadi loyal (Bruner dan Kumar, 2015). Hal ini yang menunjukkan bahwa keyakinan tentang harga dan karakteristik produk merupakan faktor utama yang mempengaruhi keputusan pembelian (Iswayanti, 2010).

Berdasarkan pernyataan diatas penulis beranggapan bahwa harga dan karakteristik produk berpengaruh terhadap keputusan pembelian. Konsumen yang merasa puas akan meningkatkan keputusan pembelian sehingga tujuan perusahaan tercapai.

\section{Kesimpulan dan Rekomendasi}

Pengaruh karakteristik produk terhadap keputusan pembelian pad aanggota Kaskus Innova Owner Community dapat dilihat dari dimensi-dimensinya yang terdiridari brand dan service yang berada pada kategori cukup tinggi. Temuan tersebut menunjukan bahwa karakteristik produk mobil Innova dianggap cukup baik.

Hasil penelitian menyatakan bahwa harga dan karakteristik produk memiliki pengaruh positif terhadap keputusan pembelian dengan pengaruh yang cukup tinggi. Temuan tersebut menunjukan bahwa semakin tinggi penerapan harga dan karakteristik produk, maka semakin tinggi pula keputusan pembelian mobil Innova pada anggota Kaskus Innova Owner Community.

Tanggapan anggota terhadap indikatorindikator karakteristik produk memiliki pengaruh yang signifikan terhadap keputusan pembelian dan berada pada tingkat yang cukup tinggi, namun masih terdapat beberapa penilaian anggota terhadap karakteristik produk yang dinilai kurang. Pada karakteristik produk penilaian yang kurang adalah terdapat pada dimensi feature yang menunjukkan bahwa pemberian informasi pribadi kepada penjual, melakukan transaksi, serta bersedia untuk mengikuti saran atau permintaan dari penjual tidak penting dalam transaksi penjualan mobil dan diartikan bahwa karakteristik produk dianggap masih rendah. Para penjual memerlukan usaha lebih dalam membentuk kepercayaan pada benak konsumen untuk menumbuhkan keputusan 
membeli mobil dengan meningkatkan feature atau kemampuan penjual, memberikan nilai lebih dalam berjualan.

Untuk meningkatkan keputusan pembelian, perusahaan harus bisa meyakinkan konsumen untuk melakukan keputusan pembelian produk yang ditawarkan melalui peningkatan inovasi produk oleh perusahaan, maka penulis merekomendasikan agar perusahaan harus lebih agresif lagi dalam menarik konsumennya, agar konsumen tersebut melakukan pembelian seperti halnya perusahaan harus memperhatikan keunikan dan keunggulan dari produk yang dipasarkan (Rahayu, 2009).

Harga dan karakteristik produk mempunyai pengaruh yang positif terhadap keputusan pembelian. Hal ini menunjukkan bahwa semakin baik harga dan karakteristik produk maka akan semakin baik pula keputusan pembelian maka penulis merekomendasikan agar perusahaan menjaga dan menetapkan harga dan karakteristik produk yang sudah terbentuk demi mencapai keputusan pembelian mobil Toyota Innova.

\section{DAFTAR PUSTAKA}

Adirama, A. (2012).

Automotifzone.com. (2015). keputusan pembelian otomotif masyarakat modern Indonesia.

Deniami dan Lisnawati. (2016). Analisis Persepsi Virtual Brand Community Terhadap Kinerja Ekuitas Merek Disposable Diaper Merek Sweety (Survei Padaanggota Fan Page Facebook Bunda Cermat).

Hasan. (2011). Harga, Kualitas dan Merek terhadap loyalitas konsumen.

Hidayat, Elita, dan Setiaman. (2012). Faktor yang mempengaruhi keputusan pembelian.

Irawan, D. D. (2015). Pengaruh Brand Image Terhadap Keputusan Pembelian.

Iswayanti. (2010). karakteristik Pemasaran stratejik.

Machfoedz, A. (2010). Pemasaran global.
Manullang. (2012). Analisis Brand Equity Terhadap Keputusan Pembelian.

Ma'ruf, A. (2011). Millenial Purchase Decision.

Monshuwe. (2014).

Philip Kotler dan Peter Keller. (2012). Marketing.

Rahayu, A. (2009). Pengaruh Inovasi Produk Terhadap Keputusan Pembelian Produk Audio Sony (Survei Pada Konsumen Di Toko Aneka Irama Jalan Abc Bandung).

Saladin. (2013). penghasilan berpengaruh terhadap keputusan pembelian.

Schiffman dan Kanuk. (2014). Pemasaran Modern.

Seok dan Tan. (2013).

Subagyo. (2010). meningkatkan pemasaran modern.

Tanjungsewu dan Lisnawati. (2016). Pengaruh Customer Relationship Management Terhadap Loyalitas Nasabah(Survei pada Nasabah Asuransi Jiwa Prudentual Cabang Kota Bandung).

Tha Kur dan Srivastava. (2013). Pengaruh Keputusan Pembelian.

Tjiptono, F. (2012). Pemasaran Modern.

Ulus, Wangko, Evelina. (2013). Faktor pendukung keputusan pembelian Mobil MPV di Indonesia.

Younus, 2. (2015). Perkembangan keputusan pembelian otomotif di indonesia. 95 140. 